\title{
The Admissibility of Spontaneous Declarations
}

Is a statement made shortly after, and in regard to, an accident by one who was the cause of, or involved in it admissible in evidence in California? The cases on this subject are in almost hopeless confusion.

In Salvo v. Market Street Ry., the court called attention to the existence of two conflicting lines of cases upon the subject. It held that the "majority view" was to be found in the case of Williams v. Southern Pacific Co., ${ }^{2}$ in which the court said:

"Expressions of persons who are actors, made during the occurrence, may generally, but not always, be proved. If spontaneous, and caused by the event, they may nearly always be shown. But if, afterwards, no matter how shortly afterwards, there is an attempt to explain what has happened, or to account for it, or to defend one's self, or the like, it is incompetent, and inadmissible as res gestae."

Accordingly the district court of appeal held that a conversation with the motorman of the defendant company "immediately after the impact" in which he said that he was looking at his watch at the time and did not see the plaintiff, was inadmissible in view of the objection interposed that the evidence was hearsay and not part of the res gestae. The supreme court demed a hearing in the case.

But a few months later in another district, Justice York, speaking for the court, held that the remark of defendant's driver made "immediately after the accident occurred," "It is my fault, I should not have been looking around" was admissible. ${ }^{3}$ The supreme court likewise demied a hearing in this case. Later cases have but added to the uncertainty of the law on the subject.4

In the opimion of the writer, this confusion is due in part to the failure of the courts of this state definitely to decide upon the theory which shall govern im determining the admissibility of such evidence, and in part to their hesitancy to leave to the trial courts the determination of the circumstances under which such statements were made.

1 (1931) 116 Cal. App. 339, 2 P. (2d) 585. case).

2 (1901) 133 Cal. 550, 554, 65 Pac. 1100, 1102 (italics added by court in Salvo

3 Coryell v. Clifford F. Reid Inc. (1931) 117 Cal. App. 534, 4 P. (2d) 295.

4 Losleben v. California State Life Ins. Co. (1932) 119 Cal. App. 556, 6 P. (2d) 1012; Bodholdt v. Garrett (1932) 122 Cal. App. 566, 10 P. (2d) 543. In People v. Mahoney (1927) $201 \mathrm{Cal}$. 618, 258 Pac. 607, the court held that in a trial on a charge of manslaughter evidence of the cries of imjured persons uttered immediately after the collapse of the structure which the defendant had erected, and the collapse of which had resulted in the indictment, was inadmissible. Justices Seawell and Curtis dissented from the portion of the opinion so holding. 
The question under consideration was passed upon at an early date in a clear-cut opinion, ${ }^{5}$ which, if followed, would have prevented the confusion that exists today. In that case the defendant was prosecuted for murder. The evidence showed that less than a minute after the homicide had occurred, but in the absence of the defendant, the victim of the shooting told the witness the circumstances of the shooting. The objection was interposed that the statements offered were "not made at the very time of the shooting but after the shooting had been concluded." The supreme court held that the declarations were made under such circumstances and in such connection with the main fact as to render them admissible as part of the res gestae. Said the court:

"Declarations to be a part of the res gestae, are not required to be precisely concurrent in point of time with the principal fact. If they spring out of the principal transaction, if they tend to explain it, are voluntary and spontaneous, and are made at a time so near it as to preclude the idea of deliberate design, then they are to be regarded as contemporaneous, and are admissible." 6

As authorities, the court cited Greeuleaf on Evidence and cases from Georgia and Massachusetts.

But the law was not allowed to stand as thus laid down. In People v. Ali Lee, ${ }^{7} \mathrm{Mr}$. Justice Sharpstein, who wrote the opinion, refused to follow People v. Vernon, ${ }^{8}$ and held that anything said after the commission of a homicide, even though said "immediately thereafter" as in the situation presented to the court, was inadmissible, as not a part of the res gestae. 9 One Justice concurred in this holding. Two Justices concurred in the judgment of reversal on another ground, while one Justice dissented. Nevertheless, the opinion of Justice Sharpstein has been frequently cited with approval by the appellate courts of Califorma. ${ }^{10}$

The opinion is a curious one in the striking absence of any substantial justification for the disregard of a prior opinion rendered by a unamimous court. No American cases are cited as authorities. The court mentioned as authorities supporting the Vernon case two well known English cases. ${ }^{11}$ But, said the court, those two cases had been

5 People v. Vernon (1868) 35 Cal. 49.

6 Ibid. at 51 .

7 (1882) 60 Cal. 85.

8 Supra note 5.

- Criminal cases are taken into consideration in this discussion since the rule is the same as in civil cases. See 2 Bishop, Crominar Procedure (2d ed. 1913) $\$ 1080$.

10 People v. Wong Ark (1892) 96 Cal. 125, 30 Pac. 1115; People v. Lane (1893) 100 Cal. 379, 34 Pac. 856; People v. Wong Loung (1911) 159 Cal. 520, 114 Pac. 829; Losleben v. California State Life Ins. Co., supra note 4. 325.

11 Thounpson v. Trevanion (1694) Skinn. 402; Rex v. Foster (1834) 6 C. \& P. 
criticized by Mr. Roscoe, the well-known author of a leading English text book .on evidence in criminal cases. It subsequently developed that the passage criticizing the two English cases referred to, was not the work of Mr. Roscoe, but had been added by a young barrister of five years' standing, who had edited an edition of Roscoe's treatise. ${ }^{12}$ The one case cited by the court in support of its holding, that the testimony was inadmissible, was Rex v. Bedingfield, ${ }^{13}$ which had been decided in England a few years before. The opinion in that case had been severely criticized by Taylor, the author of the leading English text book on evidence of that period, in a public letter which he had written to the London Times. Our supreme court quotes from the answer of Chief Justice Cockburn, in support of his ruling in that case, but without mentioning the reasons which had caused Taylor to criticize the opinion. ${ }^{14}$

The only other authority cited by our supreme court in support of its holding is Greenleaf on Evidence, to the effect that where declarations offered in evidence are "merely narrative of a past transaction" they cannot be received as proof of its occurrence. ${ }^{15}$ From this language our court apparently drew the conclusion that all subsequent statements, regardless of the circumstances under which they are made, are necessarily "merely narrative." That such a conclusion does not necessarily follow would appear to be obvious.

The holding of Chief Justice Cockburn in the Bedingfield case, upon which our court relied, was exhaustively considered by Professor James Bradley Thayer a few years after its rendition. His conclusion was in accord with that of Taylor, that the decision was not sound, the declaration there in question having been made "immediately after the injury was received." As Professor Thayer pointed out,

"A peculiarity of the Chief Justice's view lies in requiring absolutely strict and literal contemporaneousness,-admitting, however, anything that is contemporaneous with certain acts of the accused person, although the main act in question be over. The rigor of this doctrine is clearly inconsistent with what is held in civil cases as the meaning of 'contemporaneous'; and, as las been said before, there is not, so far as the writer is aware, any acknowledged difference on this subject between cases civil and criminal. In point of principle, it scems very objectionable at tbis time of day to draw, for the first time, a line in regard to the admissibility of evidence that involves us in such refinements as those which have been indicated above. There is always advantage in having a precise rule; but there may be a precision which sacrifices too much of substance." 16

12 See Sibley, Specially Admissible Evidence-Res Gestae (1903) 19 L. Q. Rev. 203, 216.

13 (1879) 14 Cox C. C. 341.

14 The discussion referred to is reviewed by Thayer, Legal Essays (1927) 207.

151 GREENIEAF, EvIDENCE (16th ed. 1899) \$110.

16 Thayer, op. cit. supra note 14 , at 282 . 
The leading English authority of the present day agrees with the doctrine as enunciated by Professor Thayer. Mr. Phipson, after laying down the general rule that:

"Acts, declarations, and incidents which constitute, or accompany and explain, the fact or transaction in issue, are admissible, for or against either party, as forming parts of the res gesta." 17 adds,

"The declarations must be substantially contemporaneous with the fact -i.e. made either during, or immediately before or after, its occurrencebut not at such an interval from it as to allow of fabrication or to reduce them to the mere narrative of a past event."18

Many American cases, both civil and criminal, might be cited to the same effect. ${ }^{19}$

It is thus apparent that even under the orthodox res gestae doctrine, there is no necessity for the exclusion of all statements regarding the circumstances of a transaction merely because such statements may not have been made absolutely concurrent therewith. It is true that under that doctrine it is difficult, if not impossible, to mark out the limits of admissibility of such subsequent declarations. It does not get us very far to be told as Professor Thayer told us, that the phrase res gestae has some play in it, and that a declaration may be admitted if it is "so close to the act that it is as if it were a part of the fact." 20

Fortunately, we are no longer limited to the res gestae doctrine as our sole justification for admitting the class of declarations under consideration. Professor Wigmore, holding, as have various writers in recent years, ${ }^{21}$ that the res gestae doctrine is inadequate for the purpose, has enunciated as a new and additional exception to the hearsay rule, having no connection with the res gestae doctrine, the theory of "Spontaneous Exclamations," as authority for their admission in evidence. ${ }^{22}$ This theory was first formulated by him in 1898, when he edited the sixteenth edition of Greenleaf on Evidence. He there referred to a class of cases decided in comparatively recent years, which, although commonly treated under the res gestae doctrine, in fact form a separate and distinct exception to the hearsay rule. The theory underlying this

17 Phipson, Evidence (6th ed. 1921) 55.

18 Ibid. 58.

10 See 22 C. J. (1920) 463.

20 ThaYER, op. cit. supra note 14, at 283. Another difficulty, not often adverted to, presents itself if such declarations are admitted under the res gestae doctrine. In that case there is serious doubt whether or not the declarations may be considered as tending directly to prove the truth of the matters stated. See PHIPson, op. cit. supra note 17, at 60, and American and English authorities there cited. Also see THAYER, op. cit. supra note 14, at 288.

21 Morgan, A Suggested Classification of Utterances Admissible as Res Gestae (1922) 31 YALE L. J. 229.

223 WigMrore, Evidence (2d ed. 1923) \$1745. 
new classification, he pointed out, was that the circumstances of an occasion might "so excite and control the mind of the speaker that his statements are natural and spontaneous and therefore sincere and trustworthy." 23 Under this theory the test to be applied in determining whether a declaration has been made too long after the occasion that provoked it to render it admissible is simple. It must have been made, says Professor Wigmore, quoting Mr. Justice Nisbet in Mitchum v. State ${ }^{24}$ ". . . at a time so near . . ., as reasonably to preclude the idea of deliberate design."

The idea of increasing the exceptions to the hearsay rule had been considered by Professor Thayer at an earlier date. He had noted the tendencies of some courts to regard a hearsay statement as admissible if it was "one of a set of facts giving and reflecting credit, each to the other, on the principle of circumstantial evidence," which, it will have been noted, is the basis underlying Wigmore's new exception. But to Professor Thayer this suggested confusion, for, he said: "Our law really goes but a very little way in that direction." 25 He admitted that hearsay statements often derive much credit from the circumstances under which they are made, and cited as examples, declarations which are admitted as part of the res gestae. But to him the idea of making any such general extension of the hearsay rule was too far reaching to be practical.

Wigmore, however, concluded that the cases did at least justify the creation of this particular addition to the exceptions to the hearsay rule. When, a few years later, he brought out his own monumental treatise on evidence, Professor Wigmore retained his new exception covering spontaneous exclamations and amplified his views on the subject. As in so many other instances, his views on this particular subject have had far reaching results, and the cases are now numerous in which Wigmore's treatise has been cited as authority upon this subject.

It will be recalled that the California Supreme Court had originally taken the view subsequently enunciated by Professor Wigmore insofar as it required subsequent statements to be spontaneous, although treating the situation as involving an application of the res gestae doctrine. In the Vernon case $^{26}$ it was held that declarations were admissible if "made at a time so near as to preclude the idea of deliberate design." Again, in Lloyd v. Boulevard Express ${ }^{27}$ the court took the same view of

23 GreenLEAF, op. cit. supra note 15, at 264.

24 (1852) $11 \mathrm{Ga} .615,627$. 552.

25 Thayer, Prelmomari Treatise on Evinence at the Common Law (1898)

26 Supra note 5, at 51 .

27 (1926) 79 Cal. App. 406, 249 Pac. 837, Sup. Ct. hearing den., Nov. 26, 1926. 
the question. It there held that statements made by the driver of an automobile immediately after an accident, in which he admitted his negligence, were admissible as against his employer. Said the court:

\begin{abstract}
"Questions as to the admissibility of such statements as part of the res gestae depend upon whether such statements are the emanations of the acts done, before the excitement usually incident to an accident causing great injury has subsided, or are the statements made after the excitement has subsided, and the witness has time to calculate a policy to be pursued. ... If the statement of the employee is spontaneous, that is, made at the time of the accident and during the excitement attending it, before the employee has time to reflect upon the consequences of his statement, or to fabricate evidence against his employer, it is admissible against the employer." 28
\end{abstract}

Moreover, and to this we call particular attention, the appellate court held that "... the trial judge before whom the witness appeared is better prepared to pass upon the evidence upon which the admissibility of such statements depend than is an appellate court and his ruling should not be disturbed unless he has abused his discretion." 29

Notwithstanding this clear-cut ruling on the subject, supported as it was by substantial authority, to the effect that subsequent statements under proper circumstances are admissible, our appellate courts have refused to take any definite position on the subject. This is due in part, as will have appeared, to the insistence of our courts on adhering to the res gestae doctrime and to the construction placed upon it by some authorities that declarations are not admissible under that doctrine unless strictly contemporaneous. It is also due in part to the hesitancy of the courts to leave the final determination of the question of the spontaneous character of the statements made to the trial court, particularly in cases in which the result may be to bind an employer by a statement made by his employee following the occurrence of an accident. Of course, if the declaration is admitted under this doctrine, it is admissible against the employer as well as the employee. ${ }^{30}$ The courts instinctively hark back to the long settled rule that an employee may not bind his employer except by declarations made by him during the course of his employment. But an employee may testify against his employer and by such testimony affect his einployer adversely. This is due to the fact that when testimony is given by him he is under oath. The courts seein to overlook the fact that the theory underlying all of the exceptions to the hearsay rule is that the circumstances surrounding the statements admitted constitute a circumstantial guarantee of their

28 Ibid. at 411,249 Pac. at 839.

$29 \mathrm{Ibid}$. at 412,249 Pac. at 839. 606,609 .

30 See Shaver v. United Parcel Service (1928) 90 Cal. App. 764, 770, 266 Pac. 
truthfulness, which is an adequate substitute for the oath. ${ }^{31}$ But this phase of the question has received very little attention from the courts.

Our courts should adopt some definite theory and take a definite stand upon this subject, so as to eliminate the present uncertainty. The res gestae doctrine is now considered by many courts and law writers to be unsatisfactory and inadequate. ${ }^{32}$ As Mr. Justice Melvin said some years ago "Definitions of res gestae are as numerous as prescriptions for the cure of rheumatism and generally about as useful." 33 In any event, whether the res gestae doctrine be abandoned or not, the appellate courts should at least follow the rule admitting subsequent declarations, provided the trial judge in his discretion concludes that the statements are spontaneous, and only interfere when it clearly appears that the lower court has abused that discretion. It is true that this gives what might seem a dangerous latitude to a trial judge. But no other logical alternative is apparent. A similar discretion is given to trial judges under corresponding circumstances with no apparent injury resulting therefrom. Moreover, as Professor Wigmore has said:

"There is a lamentable waste of time by Supreme Courts in here attempting either to create or to respect precedents. Instead of struggling weakly for the impossible, they should decisively insist that every case be treated upon its own circumstances. They should, if they are able, lift themselves sensibly to the even greater height of leaving the application of the principle absolutely to the determination of the trial Court. Until such a beneficent result is reached, the lucubrations of Supreme Courts over the details of each case will continue to multiply the tedious reading of the profession." 34

To say that a statement made during the occurrence of an accident is admissible but that it is inadmissible if made immediately thereafter and with the same circumstantial sanctions surrounding it, is to sacrifice substance to form.

The basic reason, we submit, for the reluctance of our appellate courts to allow such subsequent statements is that they are fearful of leaving to our trial courts the determination of the question of the spontaneousness of the utterances, particularly in jury trials during the course of which the question most frequently arises. The fear of the misuse of evidence by juries was frankly conceded by Mr. Justice Coleridge in the leading case of Wright v. Doe d. Tatham, in which he

31 It has been pointed out that although the declarant is more apt to speak truthfully under strong excitement than otherwise, he is less apt to speak correctly. Hutchins and Slesinger, Some Observations on the Law of Evidence (1928) 28 Cor. L. Rev. 432.

32 See Morgan, loc. cit. supra note 21, and opinions on the subject referred to therein.

33 Estate of Gleason (1913) $164 \mathrm{Cal} .756,762,130$ Pac. 872, 875.

343 WIGMORE, EVIDENCE (2d ed. 1923) \$1750, quoted with approval by the Supreme Court of Washington in Walters v. Spokane International Ry. (1910) 58 Wash. 293, 298, 108 Pac. 593, 595. 
said: ${ }^{35}$ "What may be a safe rule when the same judge decides both law and fact may be dangerous when the fact is entrusted to the jury." The same attitude is evinced by our courts when they distinguish between court and jury trials, and hold, as they have done on various occasions, that where a trial is held without a jury it will be assumed on appeal that the court in reaching its conclusions disregarded any incompetent testimony which was admitted. ${ }^{36}$

But the old attitude of the courts in regard to juries has been changing for some time past. As Professor Thayer pointed out, "Judges are, in general, less afraid of juries now than they used to be." $37 \mathrm{He}$ quotes with approval the remark of Chief Justice Cockburn in Regina v. Birmingham, " "People were formerly frightened out of their wits about admitting evidence, lest juries should go wrong. In modern times we admit the evidence, and discuss its weight.' " 39

When the New York draft of the Code of Civil Procedure was prepared by David Dudley Field and his associates, they pointed out that the fundamental difference between the system of evidence which they had provided for and the system then in common use was that the former

"goes upon the principle of admission, the latter upon the system of exclusion. Admission is the rule here; exclusion is the rule of the common law. Let in all the hight possible, we ask. Not so the common law; exclude the light, it says, lest perchance it deceive you; unmindful, as it appears to us, that poor light is better than none." 40

Our appellate courts have occasionally expressed themselves in the same veim. As Presiding Judge Harrison said in Moody v. Peirano:41

"The tendency of moderu decisions is to admit any evidence which may have a tendency to illustrate or throw any hight on the transaction in controversy, or give any weight in determining the issue, leaving the strength of such tendency or the amount of such weight to be determined by the jury; and in determining the relevancy of evidence that may be offered upon an issue of fact much depends upon the nature of the issue to sustain which or against which it is offered, and a wide discretion is left to the trial judge in determining whether it is admissible or not."

The failure to take this liberal view of the application of the rules of evidence has done much to rob the courts of their former jurisdiction over many subjects. As one of the leading American jurists of modern times, the late Chief Justice Winslow of the Supreme Court of Wisconsin, has pointed out, nothing is more significant in modern legislation

35 (1838) 5 Cl. \& Fin. 670.

36 Roth v. Thomson (1919) 40 Cal. App. 208, 216, 180 Pac. 656, 660; Watt v. Copeland (1928) 92 Cal. App. 161, 170, 267 Pac. 928, 931.

37 TenaXer, loc. cit. supra note 14.

38 (1861) 1 B. \& S. 763, 767.

39 TreAYER, op. cit. supra note 14, at 282.

40 N. Y. CODE Crv. Proc. (1850) p. 715, $\$ 1708$.

41 (1906) 4 Cal. App. 411, 418, 88 Pac. 380, 382; quoted with approval in People v. Mooney (1918) 177 Cal. 642, 655, 171 Pac. 690, 695. 
than the tendency to take from the courts the duty of settling disputed questions of fact and imposing it upon arbitration committees or administrative boards. He attributes this largely to the attitude of the courts toward the rules of evidence. ${ }^{42}$ Said that learned jurist:

"There is too much ground for the charge that our jury trials frequently resemble exhibitions of refined legal hermeneutics, or exercises in intellectual gymnastics for the benefit of the lawyers, rather than earnest and practical endeavors to determine a disputed question of fact for the benefit of chents.

"Take, for instance, the ancient rule of evidence excluding hearsay testimony. The general principle that hearsay evidence is apt to be unreliable is certainly correct. It may be easily manufactured, it incurs the risk of error resulting from two fallible memories instead of one, and the original teller of the tale is not before the jury nor can be be put under oath. Nevertheless, the enforcement of an inflexible rule that hearsay evidence is never to be received and that if received the judgment must be reversed and the action retried does not strike the practical layman as good common sense, and he has much to justify that conclusion. . . .

"The fact is that we are constantly acting on hearsay evidence in the most important affairs of life. The rigid rule of exclusion originated at a time when jurymen were supposed to be mentally unable to hear a piece of hearsay evidence without giving it the same weight as the direct evidence of a truthful witness, a time when they were treated as children who could not be trusted to act hke adult reasonable beings but must be provided with 'blinders' to prevent the eyes from wandering outside of a certain very narrow field of vision.

"These conditions have changed. Juries selected under modern laws are generally composed of practical, level-headed men of affairs who are entirely capable of making the proper allowance for the inherent weaknesses of hearsay evidence and who want to hear the entire case just as an arbitrator would.

"My suggestion is that the rule should be that hearsay evidence is prima facie incompetent but that the trial court in its discretion may admit it when of opinion that it possesses probative value and that such admission is not to be considered as error except in case of an abuse of discretion."

Although no appellate court known to the writer has enunciated the advanced view expressed by Judge Winslow in the last sentence quoted, much may be said in favor of it. But no such far reaching reform is here advocated. We but suggest that in passing upon the question of the admissibility of evidence of the type herein considered, the appellate courts definitely abandon the requirement of absolute contemporaneousness, and also that they leave to the trial courts the determination of the spontaneous character of statements offered in evidence, interfering only in cases where it appears that the discretion so exercised has been abused. Otherwise, we must continue to muddle along, as we have been doing for some time past, with no definite rule on the subject.

San Francisco, Californda.

Robert L. McWilliams.

42 Winslow, A Legislative Indictment of the Courts (1916) 29 Harv. L. REv. $395,399-400$. 